\title{
Fear Assessment in Brazilian Children: The Relevance of Dental Fear
}

\author{
Antonio Bento Alves de Moraes ${ }^{1}$ \\ Gláucia Maria Bovi Ambrosano \\ Rosana de Fátima Possobon \\ Universidade Estadual de Campinas \\ Áderson Luiz Costa Junior \\ Universidade de Brasília
}

\begin{abstract}
Fear frequently interferes with dental treatment procedures, producing delays and poor technical quality results. Patients exhibit avoidance and escape behaviors that may be related to aversive childhood experiences in dental treatment situations. The aim of this study was to identify the most frequent children's fears, including dental ones, using an adaptation of the FSSC-R. This instrument was used to assess 549 children divided in three groups: (G1) private school children, (G2) public school children and (G3) public school children who were surveyed during dental treatment. Results indicated higher dental fear scores for females when compared with male children. Considering all groups studied, "injection" was the $5^{\text {th }}$ higher fear for the group G3, $8^{\text {th }}$ for the group G1 and $14^{\text {th }}$ for the group G2. Family relationship items such as "parents fighting", "parents yelling at you", "hearing my parents argue", were considered frequent fears, suggesting that family conflicts may contribute to children's emotional problems.
\end{abstract}

Key words: dental fear; pediatric dentistry; children; FSSC-R.

\section{Avaliação do Medo em Crianças Brasileiras: A Relevância no Medo Odontológico}

\begin{abstract}
RESUMO - O medo de dentista pode aumentar a duração do tratamento odontológico e produzir resultados aquém do esperado. As crianças exibem comportamentos de fuga ou esquiva que podem estar relacionadas à situação de tratamento odontológico. Este estudo investigou as principais fontes de medo, inclusive medo de dentista, em crianças, utilizando-se uma versão adaptada do FSSC-R. O instrumento foi aplicado a 549 crianças divididas em três grupos: G1 - crianças de escola particular; G2 - crianças de escola pública e; G3 - crianças de escola pública que foram avaliadas durante tratamento odontológico. Observaram-se escores mais elevados de medo para meninas, quando comparados a meninos. Considerando todos os grupos, a "injeção" foi o quinto estímulo de medo para G3, o oitavo para o G1 e o décimo quarto para o G2. Itens de relações familiares, como "discussão entre pais", "pais gritam com você" e "ouvindo meus pais discutindo", foram considerados geradores de medo, sugerindo que conflitos familiares podem contribuir para o desenvolvimento de transtornos emocionais das crianças.
\end{abstract}

Palavras-chave: medo de dentista; odontopediatria; crianças; FSSC-R.

Several authors report that fear and anxiety are closelyrelated but not interchangeable concepts (Locker, Liddel \& Shapiro, 1999; Muris, Merckelbach, Ollendick, King \& Bogie, 2002). A learning paradigm has been used to understand these concepts, suggesting fear as a variant of anxiety (Bowlby, 1973/1984; Moraes \& Pessotti, 1985; Ten Berge, Veerkamp \& Hoogstraten, 2002). Specifically, fear is an emotional reaction caused by particular external stimuli such as parental divorce or distance, animals, darkness, and invasive medical and dental procedures (Pavuluri, Henry \& Allen, 2002). Besides, fear may be defined as a normal reaction to threats and often has survival values (Ollendick, Yule \& Ollier, 1991).

Fear onset in young children might be related to different contexts, being the dental setting one of them. (Pavuluri et al.,

1 Endereço: Faculdade de Odontologia, Av. Limeira, 901, Piracicaba, SP, Brasil 13414-018. E-mail: abento@fop.unicamp.br ou aderson@unb.br
2002). In this case, dental fear frequently influences patients' behavior, delaying treatment and producing unsatisfactory technical results. Fearful patients postpone dental treatment until it becomes extremely necessary. Dental treatment avoidance may be the result of aversive painful childhood experiences (Milgron, Fiset \& Melnick, 1988).

Though there are many dental and non-dental reports of the relationship between fear and pain, the literature is still not clear about the distinction between psychological and physiological factors that may influence the patient's behavior during dental routines, as the procedure of dental injection. Factors such as fear are clearly capable of influencing patient response to painful or other stimuli applied after administration of local anesthetic. Such factors may contribute to inadequate anesthesia. Moreover, the relationship between these variables may be reciprocal: fear leading to inadequate anesthesia and being treated with inadequate anesthesia serves to increase fear (Milgrom, Weinstein, Kleinknecht \& Getz, 1980; Possobon, 2003). 
In a previous study, Dental Fear Survey (DFS) has been used to assess 374 Brazilian University students (mean age of 23), showing high fear scores for $13 \%$ of the subjects (Cesar, Moraes, Milgrom \& Kleinknecht, 1993). There was no difference in fear scores for both genders, but older students reported higher fear scores when compared to younger students. On the other hand, another study has shown no correlation between fear level and age for Brazilian high school students (15 to 20 years), but fear score records for female students were observed to be seven times higher than for male students (Moraes, Milgrom, Tay \& Costa, 1994).

The difference between the constructs of fear and anxiety, coupled with the importance of differentiating between them, have resulted in the development of separate selfreport instruments to assess anxiety and fear in children (Pavuluri et al., 2002). Most studies on children dental fear, for example, have been based on surveys listing a wide range of fear-evoking stimuli (Muris, Merckelbach, Meesters \& Van Lier, 1997; Singh, Moraes \& Ambrosano, 2000). The Fear Survey Schedule for Children - Revised (FSSC-R) may be considered as the most common instrument, in which children are asked to indicate their fear in a three-point scale - "none", "some" or "a lot" - considering 80 specific stimuli or situations (Muris, Merckelbach, Ollendick, King, Meesters \& Kessel, 2002; Ollendick, 1983).

The FSSC-R scores correlated substantially with other childhood anxiety and fear measures and have been found to be useful in differentiating among various types of specific phobias, diagnosed in different countries (Weens, Silverman, Saavedra, Pina \& Lumpkin, 1999). In addition, a consistent finding in FSSC-R previous studies have shown that children's fear is consistently related to death and physical injury. Some previous studies have reported the highest fear levels for the following items: not being able to breathe; bombing attacks; being run over by a car; getting burned by a fire; falling from high places; robberies at home; earthquakes; illness; death; and snakes (Ollendick \& King, 1994; Ollendick et al., 1991; Scherer \& Nakamura, 1968).

The aim of this study was to identify the most common fears, including dental fears in a sample of Brazilian children.

\section{Method}

\section{Subjects}

A modified version of the "Fear Survey Schedule for Children" (FSSC) was individually used for 549 subjects, 6 to 10 years of age, (52\% female and $47 \%$ male), divided into three groups: $\mathrm{G} 1$ - private school children $(n=144)$; G2 - public school children ( $n=251)$; and G3 - public school children who, unlike the others, were surveyed during dental treatment $(n=154)$. The public schools selected were inserted in a region of low social-economical level population. On the order hand, the private schools belonged to a high medium class area. Dental services were not available in the private school. Children were not submitted to a social demographic measurement instrument. Parental consent was obtained for $100 \%$ of the subjects through a consent form, detailing the project's purpose.

\section{Procedures}

One of the most widely used self-report instruments in the study of children's fears is the Fear Survey Schedule for Children-Revised (FSSC-R; Ollendick, 1983). The FSSC-R contains the original 80 items of the Fear Survey Schedule for Children (FSSC; Scherer \& Nakamura, 1968) with a reduced 3-point item response scale ranging from none to a lot, and has acceptable internal consistency.

Of the 80 items in the original scale, one clinical psychologist and one experienced dentist selected 50

\begin{tabular}{lll}
\hline Box 1. Fear Survey Schedule for Children - Revised (FSSC-R) & \multicolumn{1}{c}{ Fear Items } \\
\hline \multicolumn{4}{l}{ Dentists } & \multicolumn{1}{c}{ 18. Being away from your mother } & 35. Choking \\
1. Dogs & 19. Having a stranger touch you & 36. The sight of blood \\
2. & 20. Having somebody look at you & 37. Not being able to breathe \\
3. Being laughed at & 21. Having the nurse clean your teeth & 38. Rats \\
4. Doctors & 22. The dentist's drill & 39. Having to go to the hospital \\
5. Dark & 23. The sight of the dentist's drilling & 40. Ghosts \\
6. Lightning & 24. The noise of a dentist's drilling & 41. Having to eat the food I don't like \\
7. Thunder & 25. Having somebody put instruments in your & 42. Getting lost \\
8. Strangers & mouth & 43. Hearing my parents argue \\
9. Loud noises & 26. Crying in front of other children & 44. Making mistakes \\
10. Getting caught out in the rain & 27. Parents yelling at you & 45. People in white uniforms \\
11. Being late for school & 28. Hearing other children cry & 46. Getting a poor mark at school \\
12. Having to go up to the blackboard in front & 29. Being in a crowd & \\
of the class & 30. Doing Something new & 47. Being alone \\
13. Injections (Shots) & 31. Getting burned by a fire & 48. Answering questions \\
14. Losing at a game & 32. Parents fighting & 49. Taking a test \\
15. Being called on in class & 33. Getting a haircut & 50. Getting punished \\
16. Having somebody examine your mouth & 34. Spiders & \\
17. Having to open your mouth &
\end{tabular}


items that seemed more appropriate to Brazilian children. For each item the child was asked to choose one of the following possible choices: not afraid at all, a little afraid, fairly afraid, pretty much afraid and very afraid. To facilitate children's responding, it was also used a five different stylized drawings of faces that represented each possible choice of responding.

The selection of the five different drawings was made by testing other children that were not used as subjects of the present study. Besides drawings, colors and words related to each level of fear were also tested. However, most of the children, when asked about their preference chose the drawings and words that were used with all the research subjects.

Subjects were asked to indicate with one finger the fear they felt in a five-point scale as follows: not afraid at all, a little afraid, fairly afraid, pretty much afraid, and very afraid. Five different stylized faces (e.g. :), $;, ;$, ), one for each point scale, were created to make it easier for the children to select their fear level. Experimenters marked with a pencil the fear level indicated (see Box 1).

Fear level scores range from 1 to $5(1=$ not afraid at all $5=$ very afraid). Fear items were classified using central tendency measures (mean, median and mode). Mann-Whitney ( $\alpha=$ 0.05 ) test was used to compare fear level between genders, between private and public school children, and between groups that were and were not under dental treatment during data collection. Spearman $(\alpha=0.05)$ correlation analysis was used to compare fear levels and age. Chi-Square e MannWhitney tests were used for statistical analysis.

\section{Results}

Fear intensity, concerning all fear items together (50 items), was observed to be significantly higher $(p<0.01)$ for female children. When these items were analyzed individually, 62 $\%$ also showed higher fear for girls $(p<0.05)$. Such items as "loud noise", "injection", "being away from mother", "a stranger touching you", "the sight of the dentist drilling", "the noise of a dentist's drilling", "choking", "blood", "not being able to breathe", "having to go to the hospital", and "people in white uniforms" may be related to dental treatment. There was no significant correlation between age and fear intensity for all groups ( $r=-0.09$ and $p>0.05)$.

All tables (1,2, and 3 ) show central tendency measurement scores, considering all groups: G1 - private school children; G2 - public school children; and G3 - public school children undergoing dental treatment during data collection.

Table 1 shows the 10 highest fear scores for all groups: The items "getting burned by a fire" and "choking" were the most frequent fears. Injection fear was ranked $8^{\text {th }}$ for G1 and $5^{\text {th }}$ for G3. Since injection fear for G2 was ranked $14^{\text {th }}$, it is not indicated in the table. Items related to family lifestyle, such as "parents fighting", "hearing my parents argue", "parents yelling at you" showed the highest fear scores.

Table 2 shows results for G1 and G2, concerning dental treatment related items. Public school children (G2) showed higher fear scores for the following items: "having to open your mouth", "being away from your mother", "having somebody put instruments in your mouth", "not being able to
Table 1. Mean, median, and mode of the 10 "highest" fears in decreasing order

\begin{tabular}{|llccc}
\hline \multicolumn{1}{c}{ Fear } & Media & Median & Mode \\
\hline G1 & Private School & & & \\
$1^{\text {st }}$ & Getting burned by a fire & 4.08 & 5 & 5 \\
$2^{\text {nd }}$ & Choking & 3.82 & 4 & 5 \\
$3^{\text {rd }}$ & Having a stranger touch you & 3.52 & 4 & 5 \\
$4^{\text {th }}$ & Getting lost & 3.30 & 3 & 5 \\
$5^{\text {th }}$ & Not being able to breathe & 3.28 & 3 & 1 \\
$6^{\text {th }}$ & Strangers & 3.13 & 3 & 2 \\
$7^{\text {th }}$ & Hearing my parents argue & 2.80 & 3 & 1 \\
$8^{\text {th }}$ & Injection & 2.63 & 2 & 1 \\
$9^{\text {th }}$ & Getting punished & 2.56 & 2 & 1 \\
$10^{\text {th }}$ & Parents yelling at you & 2.51 & 2 & 1 \\
\hline G2 & Public School & & & \\
$1^{\text {st }}$ & Getting burned by a fire & 3.99 & 5 & 5 \\
$2^{\text {nd }}$ & Choking & 3.59 & 4 & 5 \\
$3^{\text {rd }}$ & Having a stranger touch you & 3.51 & 4 & 5 \\
$4^{\text {th }}$ & Getting lost & 3.22 & 4 & 5 \\
$5^{\text {th }}$ & Being away from your mother & 2.99 & 3 & 5 \\
$6^{\text {th }}$ & Not being able to breathe & 2.94 & 3 & 5 \\
$7^{\text {th }}$ & Hearing my parents argue & 2.93 & 3 & 5 \\
$8^{\text {th }}$ & Strangers & 2.89 & 3 & 2 \\
$9^{\text {th }}$ & Parents fighting & 2.80 & 3 & 1 \\
$10^{\text {th }}$ & Making mistakes & 2.73 & 2 & 1 \\
\hline G3 & Public School (under dental treatment) & & \\
$1^{\text {st }}$ & Getting burned by a fire & 4.08 & 5 & 5 \\
$2^{\text {nd }}$ & Choking & 4.03 & 5 & 5 \\
$3^{\text {rd }}$ & Parents fighting & 3.81 & 5 & 5 \\
$4^{\text {th }}$ & Not being able to breathe & 3.77 & 4 & 5 \\
$5^{\text {th }}$ & Injection & 3.63 & 4 & 5 \\
$6^{\text {th }}$ & Getting lost & 3.40 & 4 & 5 \\
$7^{\text {th }}$ & Hearing my parents argue & 3.38 & 4 & 5 \\
$8^{\text {th }}$ & Having a stranger touch you & 3.26 & 3 & 5 \\
$9^{\text {th }}$ & Being away from your mother & 3.06 & 3 & 5 \\
\hline
\end{tabular}

breathe", and "people in white uniform". On the order hand, Private school children (G1) showed higher fear score related to the item "having to go to the hospital" $(p<0.05)$.

Table 3 shows fear scores for G2 and G3, concerning dental treatment fear related items. It is possible to observe that fear scores were significantly higher $(p<0.05)$ for $\mathrm{G} 3$, considering the following items: "doctors", "injection", "choking", "not being able to breathe" and "being alone".

There was no statistically significant difference $(p>0.05)$ among the groups concerning the item "having a stranger touch you", to which most of the children indicated the alternative "very afraid" ( mode $=5$ ).

A more comprehensive fear analysis revealed higher fear $(p<0.05)$ for $\mathrm{G} 3$ in $50 \%$ of the 50 items of the instrument.

Figure 1 shows that $16.7 \%$ of the girls and $5.3 \%$ of the boys that were under dental treatment (G3) and $8.2 \%$ of the girls and $6.0 \%$ of the boys not under dental treatment (G2) responded as "fairly afraid", "pretty much afraid", or "very afraid" in relation to the item "dentists". 


\section{A. B. A. Moraes e cols}

Table 2. Dental treatment related items and results concerning public and private school children

\begin{tabular}{|c|c|c|c|c|c|c|c|}
\hline \multirow{3}{*}{ Fear } & \multicolumn{6}{|c|}{ School } & \multirow{3}{*}{$\begin{array}{r}\text { P(Mann } \\
\text { Whitney }\end{array}$} \\
\hline & \multicolumn{3}{|c|}{ Private $(n=144)$} & \multicolumn{3}{|c|}{ Public (n=251) } & \\
\hline & Median & Mode & Rank means & Median & Mode & Rank means & \\
\hline Dentists & 1 & 1 & 196.5 & 1 & 1 & 196.5 & 0.99 \\
\hline Doctors & 1 & 1 & 195.4 & 1 & 1 & 197.9 & 0.78 \\
\hline Strangers & 3 & 2 & 208.2 & 3 & 2 & 188.3 & 0.08 \\
\hline Loud noises & 1 & 1 & 189.4 & 1 & 1 & 201.3 & 0.28 \\
\hline Injection & 2 & 1 & 205.5 & 2 & 1 & 192.2 & 0.24 \\
\hline Having somebody examine your mouth & 1 & 1 & 187.4 & 1 & 1 & 201.6 & 0.11 \\
\hline Having to open your mouth & 1 & 1 & 185.9 & 1 & 1 & 203.3 & 0.0028 \\
\hline Being away from your mother & 2 & 1 & 174.3 & 3 & 5 & 209.8 & 0.0022 \\
\hline Having a stranger touch you & 4 & 5 & 193.0 & 4 & 5 & 198.4 & 0.64 \\
\hline Having somebody look at you & 1 & 1 & 194.5 & 1 & 1 & 198.4 & 0.78 \\
\hline Having the somebody clean your teeth & 1 & 1 & 194.8 & 1 & 1 & 196.7 & 0.82 \\
\hline The dentist drill & 1 & 1 & 190.8 & 1 & 1 & 195.0 & 0.67 \\
\hline The sight of the dentist's drilling & 1 & 1 & 182.6 & 1 & 1 & 198.9 & 0.08 \\
\hline The noise of the dentist's drilling & 1 & 1 & 195.3 & 1 & 1 & 191.7 & 0.69 \\
\hline Having somebody put instruments in your mouth & 1 & 1 & 179.1 & 1 & 1 & 201.8 & 0.0248 \\
\hline Hearing other children cry & 1 & 1 & 191.6 & 1 & 1 & 200.0 & 0.4 \\
\hline Choking & 4 & 5 & 198.8 & 4 & 5 & 195.1 & 0.75 \\
\hline The sight of blood & 1 & 1 & 193.0 & 1 & 1 & 197.6 & 0.08 \\
\hline Not being able to breathe & 3 & 1 & 183.6 & 3 & 5 & 203.8 & 0.04 \\
\hline Having to go to a hospital & 2 & 1 & 210.7 & 1 & 1 & 188.4 & 0.04 \\
\hline People in white uniforms & 1 & 1 & 186.8 & 1 & 1 & 201.9 & 0.03 \\
\hline Being alone & 2 & 1 & 204.1 & 2 & 1 & 192.2 & 0.28 \\
\hline
\end{tabular}

Table 3. Dental treatment related items and results for children that were (yes) and were not (no) under dental treatment

\begin{tabular}{|c|c|c|c|c|c|c|c|}
\hline \multirow{3}{*}{ Fear } & \multicolumn{6}{|c|}{ Public School Children } & \multirow{3}{*}{ P(Mann Whitney) } \\
\hline & \multicolumn{3}{|c|}{ Yes $(n=154)$} & \multicolumn{3}{|c|}{ No $(n=251)$} & \\
\hline & Median & Mode & Rank means & Median & Mode & Rank means & \\
\hline Dentists & 1 & 1 & 195.4 & 1 & 1 & 204.4 & 0.56 \\
\hline Doctors & 1 & 1 & 224.6 & 1 & 1 & 189.7 & 0.004 \\
\hline Strangers & 2 & 2 & 192.2 & 3 & 2 & 208.0 & 0.18 \\
\hline Loud noises & 1 & 1 & 204.2 & 1 & 1 & 202.3 & 0.86 \\
\hline Injection & 4 & 5 & 251.7 & 2 & 1 & 173.1 & 0.0001 \\
\hline Having somebody examine your mouth & 1 & 1 & 210.5 & 1 & 1 & 198.4 & 0.2 \\
\hline Having to open your mouth & 1 & 1 & 211.4 & 1 & 1 & 197.8 & 0.15 \\
\hline Being away from your mother & 3 & 5 & 206.2 & 3 & 5 & 201.0 & 0.065 \\
\hline Having a stranger touch you & 3 & 5 & 188.6 & 4 & 5 & 211.8 & 0.062 \\
\hline Having somebody look at you & 2 & 1 & 215.6 & 1 & 1 & 195.3 & 0.18 \\
\hline Having the somebody clean your teeth & 1 & 1 & 209.7 & 1 & 1 & 197.3 & 0.15 \\
\hline The dentist drill & 1 & 1 & 193.8 & 1 & 1 & 204.7 & 0.28 \\
\hline The sight of the dentist's drilling & 1 & 1 & 207.5 & 1 & 1 & 195.3 & 0.22 \\
\hline The noise of the dentist's drilling & 1 & 1 & 207.8 & 1 & 1 & 195.1 & 0.16 \\
\hline Having somebody put instruments in your mouth & 1 & 1 & 191.1 & 1 & 1 & 205.6 & 0.16 \\
\hline Hearing other children cry & 1 & 1 & 201.0 & 1 & 1 & 203.4 & 0.78 \\
\hline Choking & 5 & 5 & 217.8 & 4 & 5 & 193.0 & 0.0026 \\
\hline The sight of blood & 1 & 1 & 204.2 & 1 & 1 & 201.4 & 0.79 \\
\hline Not being able to breathe & 4 & 5 & 226.2 & 3 & 5 & 187.9 & 0.0009 \\
\hline Having to go to a hospital & 1 & 1 & 208.2 & 1 & 1 & 198.9 & 0.38 \\
\hline People in white uniforms & 1 & 1 & 208.8 & 1 & 1 & 198.6 & 0.22 \\
\hline Being alone & 2 & 1 & 218.7 & 2 & 1 & 192.5 & 0.0205 \\
\hline
\end{tabular}


It was also observed that the girls under dental treatment, when compared to those not under dental treatment, indicated greater fear of dentists (Chi-Square, $p=0.00443$ ). In relation to the boys, under the same conditions, no statistically significant difference was observed $(p=0.9546)$ according to Figure 1.

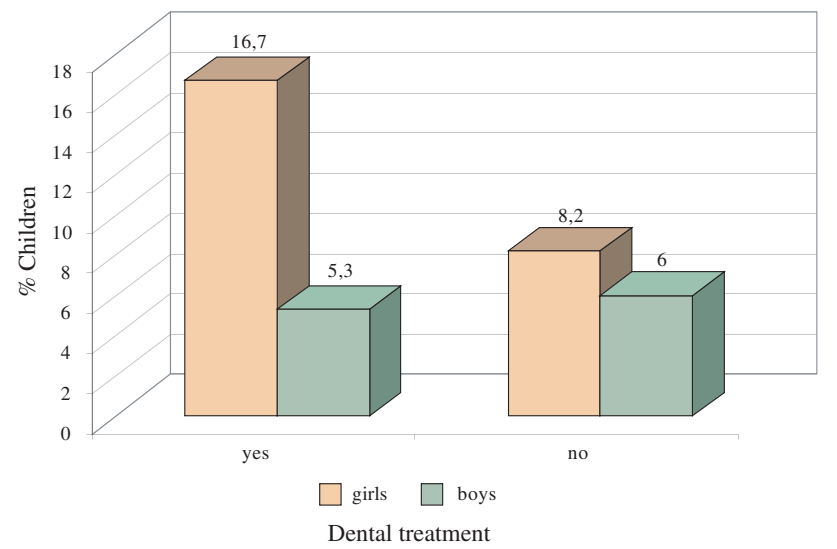

Figure 1. Relative frequency of children that were under dental treatment (yes) and were not under dental treatment (no) that chose "fairly afraid", "pretty much afraid" or "very afraid" alternatives to the item "dentists".

Considering the item "the sight of blood", $52.6 \%$ of the girls and $19.7 \%$ of the boys under dental treatment (G3) and $37.0 \%$ of the girls and $24.6 \%$ of the boys not under dental treatment (G2) responded as "fairly afraid", "pretty much afraid", and "very afraid" (see Figure 2). Girls that were under dental treatment showed to be significantly more fearful than those not under dental treatment $(p=0.0245)$. Among boys there was no significant difference $(p=0.4407)$.

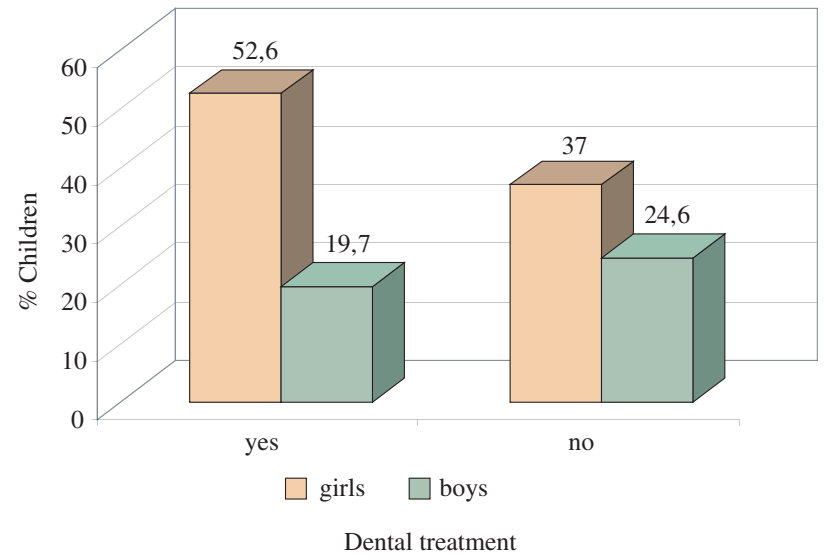

Figure 2. Relative frequency of children that were under dental treatment (yes) and were not under dental treatment (no) that chose "fairly afraid", "pretty much afraid" or "very afraid" alternatives to the item "blood".

Figure 3 shows results obtained through the question "When was your last visit to the dentist?", concerning all the children. Considering the data shown in Figure 3, it was observed that $8 \%$ of the private school children and $12 \%$ of the public school children had never gone to the dentist prior to data collection. However, $53 \%$ of the private school children and $39 \%$ public school children reported having gone to the dentist in the last 6 months before data collection

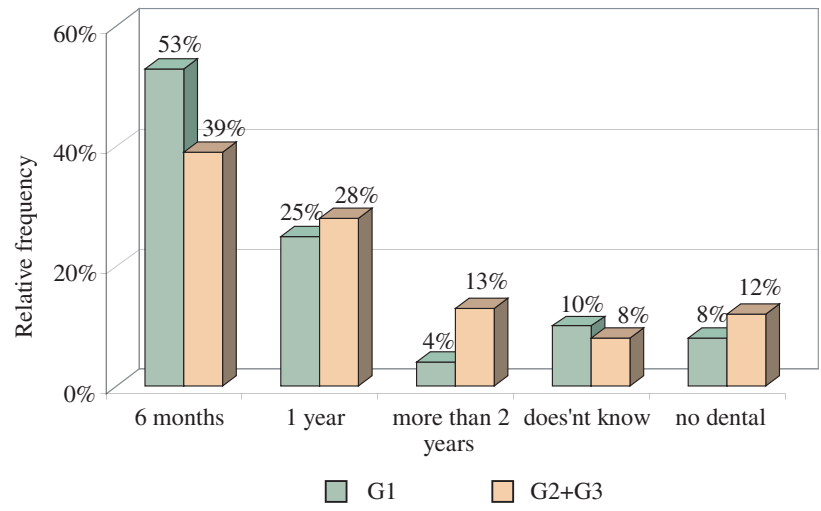

Figure 3. Relative frequency of private school children (G1) and public school children $(\mathrm{G} 2+\mathrm{G} 3)$ that answered the question "When was your last visit to the dentist?".

$(p=0.0041)$. In the present study, there was no significant correlation between "time from the last visit" and "dental fear" $(r=0.009$ e $p=0.1315)$.

\section{Discussion}

A previous study with Brazilian high school students has revealed that dental fear level in female students was seven times higher than in male students (Moraes et al., 1994). Muris and Ollendick (2002) also noted that girls clearly displayed higher levels of trait anxiety and anxiety disorders symptoms in dental settings than boys did. Similar results were observed in the present study when all fear scores were added. Fear level difference concerning both genders was observed for $62 \%$ of the items, some of which were related to dental treatment situations.

There was no correlation between fear intensity and age in this study. Similar results were found for high school subjects (Moraes et al., 1994). However, a previous study using objective self-report measures has reported more prominent age differences in the prevalence and intensity rather than in the content of fear. In addition, younger children have reported greater fear intensity than older children (Shore \& Mark, 1998).

In the present paper, the dental related items (according to Table 2 and Table 3) "choking" and "having a strange touch you" showed the highest fear level in relation to G1 and G2. In addition, Table 1 shows, among the 10 items for G3, four dental related items: "choking", "not being able to breathe", "injection" and "having a strange touch you". The item "not being able to breathe" also revealed one of the ten highest fears. In addition, high dental related fear scores were also observed for such items as "having a stranger touch you" and "not being able to breathe", except for the item "injection" which displayed high fear level for G1 and G3, but was ranked $14^{\text {th }}$ in G2. Some previous studies, employing the FSSC-R, have also reported high fear levels for the items "not being able to breathe" and "getting burned by a fire" (Ollendick \& King, 1994; Ollendick et al., 1991; Scherer \& Nakamura, 1968).

In this study, it was also observed that $8 \%$ of the private school children and $12 \%$ of the public school children have never gone to the dentist. No significant correlation was observed between "time from the last visit" and "dental fear" 
( $r=0.009$ and $p=0.1315)$. Data obtained by Geography and Statistics Brazilian Institute (IBGE, 1998), indicated that 25\% of individuals (ages 5 to 19) have never had a dental treatment experience. Dental health may be considered an important aspect in general population and fear still represents a barrier to the achievement of optimal health indexes.

On the other hand, Cesar et al. (1993) reported that high fear levels were significantly related to great intervals since the last visit.

Items related to family lifestyle, such as "parents fighting", "hearing my parents argue", "parents yelling at you" were among the highest fears (see Table 1), suggesting that patterns of raising children or family conflicts may be more directly related to children's behavior. Therefore, the present study highlights the need for further studies on the correlation between family related affairs and dental fear.

Considering the obtained results, the main conclusions are:

1. In comparison to boys, girls showed higher total fear level concerning the whole sample studied.

2. There was no correlation between total fear score and age.

3. The most prevalent fears for all groups were: "getting burned by a fire", "choking", "having a strange touch you", "not being able to breathe", "getting lost", "hearing my parents argue", and "injection".

4. Children under dental treatment showed greater fear when compared to those who were not under dental treatment in $50 \%$ of the items.

5. Injection fear was ranked $5^{\text {th }}$ for public school children under dental treatment $(\mathrm{G} 3), 8^{\text {th }}$ for private school children (G1), and $14^{\text {th }}$ for public school children not under dental treatment (G2).

6. The items "parents fighting", "hearing my parents argue", and "parents yelling at you" were among the highest, suggesting that parents' behavior evokes children emotional disturbances.

\section{References}

Bowlby, J. (1984). Separação. (A. Cabral, Trad.) São Paulo: Martins Fontes. (Trabalho original publicado em 1973).

Cesar, J., Moraes, A. B. A., Milgrom, P. \& Kleinknecht, R. A. (1993). Cross validation of a brazilian version of dental fear survey. Community Dentistry and Oral Epidemiology, 21(2), 148-150.

IBGE (1998). Acesso e utilização de serviços de saúde. Retirado em 01/11/2004, do http://www.ibge.gov.br/ home/estatistica/ populacao/trabalhoerendimento/pnad98/saude

Locker, D., Liddel, A. \& Shapiro, D. (1999). Diagnostic categories of dental anxiety: A population-based study. Behaviour Research and Therapy, 37(1), 25-37.

Milgron, P., Fiset, L. \& Melnick, S. (1988). The prevalence and practice management consequences of dental fear in a major US city. Journal of the American Dental Association, 116, 641-647.

Milgrom, P., Weinstein, P., Kleinknecht, R. \& Getz, T. (1980). Treating fearful dental patients: A patient management handbook. Virginia: Reston Publishing Company.

Moraes, A. B. A., Milgrom, P., Tay, K. M. \& Costa, S. M. (1994). Prevalence of dental fear in Brazilian high school students in
São Paulo State. Community Dentistry and Oral Epidemiology, 22(1), 114-115.

Moraes, A. B. A. \& Pessotti, I. (1985). Psicologia aplicada à odontologia. São Paulo: Sarvier \& Unicamp.

Muris, P. \& Ollendick, T. H. (2002). The assessment of contemporary fears in adolescents using a modified version of the Fear Survey Schedule for Children - Revised. Anxiety Disorders, 16(6), 567-584.

Muris, P., Merckelbach, H., Ollendick, T., King, N. \& Bogie, N. (2002). Three traditional and three new childhood anxiety questionnaires: Their reliability and validity in a normal adolescent sample. Behaviour Research and Therapy, 40(7), 753-772.

Muris, P., Merckelbach, H., Ollendick, T., King, N., Meesters, C. \& Kessel, C. (2002). What is the revised fear survey schedule for children measuring? Behaviour Research and Therapy, 40(11), 1317-1326.

Muris, P., Merckelbach, H., Meesters, C. \& Van Lier, V. (1997). What do children fear most often? Journal of Behavioral Therapy and Experimental Psychiatry, 28(4), 263-267.

Ollendick, T. H. (1983). Reliability and validity of the revised Fear Survey Schedule for Children (FSSC-R). Behaviour Research and Therapy, 21(6), 685-692.

Ollendick, T. H. \& King, N. J. (1994). Fears and their level of interference in adolescents. Behaviour Research and Therapy, 32(6), 635-638.

Ollendick, T. H., Yule, W. \& Ollier, K. (1991). Fears in British children and their relationship to manifest anxiety and depression. Journal of Child Psychology and Psychiatry, 32(3), 321-331.

Pavuluri, M. N., Henry, D. \& Allen, K. (2002). Anxiety and fear: Discriminant validity in the child and adolescent practitioner's perspective. European Child \& Adolescent Psychiatry, 11(6), 273-280.

Possobon, R. F. (2003). Efeitos do diazepam sobre os comportamentos não colaboradores de crianças em atendimento odontológico. Tese de doutoramento, Universidade Estadual de Campinas, Piracicaba.

Scherer, M. W. \& Nakamura, C. Y. (1968). A fear Survey Schedule for Children (FSS-FC): A factor analytic comparison with manifest anxiety (CMAS). Behaviour Research and Therapy, 6(2), 173-182.

Shore, G. N. \& Mark, D. R. (1998). The Fear Survey Schedule for Children-Revised (FSSC-HI): Ethnocultural Variations in Children's Fearfulness. Journal of Anxiety Disorders, 12(5), 437-461.

Singh, K. A., Moraes, A. B. A. \& Ambrosano, G. M. B. (2000). Medo, ansiedade e controle relacionados ao tratamento odontológico. Pesquisa Odontológica Brasileira, 14(2), 131-136.

Ten Berge, M., Veerkamp, J. S. \& Hoogstraten, J. (2002). The etiology of childhood dental fear: The role of dental and conditioning experiences. Anxiety Disorders, 16(3), 321-329.

Weems, C. F., Silverman, W. K., Saavedra, L. M., Pina, A. A. \& Lumpkin, W. P. (1999). The discrimination of children's phobias using the Revised Fear Schedule for Children. Journal of Child Psychology and Psychiatry, 40(6), 942-952.

Recebido em 30.03.2004

Primeira decisão editorial em 25.10.2004

Versão final em 10.11.2004

Aceito em 02.12.2004 